\title{
DESAIN PENGELOLAAN KEUANGAN PARTAI POLITIK BERBASIS DEMOKRASI MENUJU KEMANDIRIAN PARTAI POLITIK
}

\author{
Didik Sukriono \\ Program Studi Pendidikan Pancasila dan Kewarganegaraan, Universitas Negeri Malang \\ Jl. Semarang No. 5 Malang \\ Email: didik.sukriono.fis@um.ac.id
}

\begin{abstract}
This article discussed fundamental issues about the financial management of political parties and provided a solution to the problem through a design for the financial management of democratic political parties. The method used a conceptual approach. The results showed that the negative impacts that occur when financial management was bad would affect its contribution to the people. What's more when political parties have limitations in terms of structural and financial. Structural limitations were characterized by weak networks of work and organizations and oligarchic leadership. While financial limitations were characterized by political party financial dependence on donors so that political parties tend to rank the interests of contributors and forget the interests of the community. Large donors occupy strategic positions in the management of political parties or even become determinants of political party policies. For this reason, a political party financial management was needed in a democratic way and the independence of political parties becomes a necessity to realize the role and function of political parties.
\end{abstract}

Keywords: financial management, political parties, democracy and independence

\begin{abstract}
Abstrak: Kajian ini membahas permasalahan mendasar mengenai pengelolaan keuangan partai politik serta memberikan sebuah solusi terhadap permasalahan yang ada dengan membuat sebuah desain dalam pengelolaan keuangan partai politik yang berbasis demokrasi. Pendekatan yang digunakan adalah pendekatan konseptual. Hasil kajian menunjukkan bahwa dampak negatif yang terjadi apabila pengelolaan keuangannya buruk maka akan berpengaruh terhadap kontribusinya terhadap rakyat. Terlebih lagi ketika partai politik mempunyai keterbatasan dari segi struktural maupun finansial. Keterbatasan struktural ditandai dengan lemahnya jaringan kerja dan organisasi serta kepemimpinan oligarkis. Sedang keterbatasan finansial ditandai dengan ketergantungan keuangan partai politik kepada penyumbang sehingga partai politik cenderung mengutamakan kepentingan penyumbang dan melupakan kepentingan masyarakat. Penyumbang besar menduduki posisi strategis dalam kepengurusan partai politik atau bahkan menjadi penentu kebijakan-kebijakan partai politik. Untuk itu diperlukan sebuah pengelolaan keuangan partai politik secara demokrasi dan kemandirian partai politik menjadi keniscayaan dalam upaya mewujudkan peran dan fungsi partai politik.
\end{abstract}

Kata kunci: pengelolaan keuangan, partai politik, demokrasi dan kemandirian

UU No. 2 Tahun 2011 tentang Perubahan Atas UU No. 2 Tahun 2008 tentang Partai Politik, mendefinisikan partai politik sebagai organisasi yang bersifat nasional dan dibentuk oleh sekelompok warga negara Indonesia secara sukarela atas dasar kesamaan kehendak dan cita-cita untuk memperjuangkan dan membela kepentingan politik anggota, masyarakat, bangsa dan negara, serta memelihara keutuhan Negara Kesatuan Negara
Indonesia berdasarkan Pancasila dan Undang Undang Dasar Negara Republik Indonesai Tahun 1945.Artinya partai politik memiliki kedudukan dan peranan yang sangat sentral dan penting dalam setiap sistem demokrasi. Tidak ada negara demokrasi tanpa partai politik dan oleh karenanya partai politik disebut sebagai pilar demokrasi.

Konsep partai politik dalam UU di atas, menempatkan partai politik pada posisi yang 
signifikan dan menjadi poros penting dalam proses demokrasi. Partai politik tidak hanya menjadi saluran partisipasi politik warga negara, tetapi juga untuk mengintegrasikan para individu dan kelompok dalam masyarakat ke dalam sistem politik. Partai politik tidak hanya berperan dalam mempersiapkan para kader calon pemimpin bangsa untuk dicalonkan melalui pemilihan umum (pemilu) untuk menduduki berbagai jabatan dalam lembaga legislatif atau eksekutif, tetapi juga memperjuangkan kebijakan publik berdasarkan aspirasi dan kepentingan masyarakat.

Dalam konteks pelaksanaan demokrasi, partai politik memiliki fungsi sebagai penyalur artikulasi dan agregasi kepentingan politik yang paling mapan dalam sebuah sistem politik modern. Sifat penting dari partai politik menjadi semakin terlihat manakala dihubungkan dengan kepentingan publik yang perlu didengar oleh pemerintah dan parlemen. Alasan utama dari pentingnya keberadaan partai politik dalam proses demokrasi, khususnya demokrasi tidak langsung adalah karena ruang geografis yang semakin luas dan populasi penduduk yang semakin besar dalam wilayah suatu negara, sehingga dalam situasi tersebut masyarakat tidak mungkin menyalurkan aspirasinya secara langsung. Berdasarkan uraian di atas, maka secara sederhana partai politik memiliki tugas untuk menjadi "jembatan" antara rakyat dan pemerintah, sehingga partai politik merupakan salah satu pilar utama dan institusi demokrasi yang penting selain dari lembaga eksekutif, legislatif, yudikatif, pemilihan umum, serta pers yang independen dalam rangka membangun kehidupan politik yang berkualitas dan beradab.

Keberadaban dan kualitas kehidupan politik yang dimaksud adalah partai politik dengan berbagai peran dan fungsinya diharapkan mampu meredam bahkan menyelesaikan berbagai persoalan yang muncul dalam masyarakat modern seperti saat ini. Artinya keberadaban yang akan terbangun melalui partai politik dapat terwujud ketika perbedaan pendapat yang berpotensi menimbulkan konflik destruktif secara eskalatif dapat diselesaikan melalui cara-cara dialogis yang konstruktif.

Sedang dalam konteks partai politik sebagai "jembatan" komunikasi antara rakyat dan pemerintah, partai politik melalui jajaran struktural partai pada berbagai tingkatan administratif seharusnya menjadi bagian dalam kehidupan sosial dan politik dalam suatu entitas masyarakat tertentu. Partai politik dapat menempatkan posisinya secara aktif dan kreatif dalam rangka menjalankan fungsi dan tugasnya sebagai representation of idea. Partai politik bersama dengan institusi demokrasi lainnya seperti lembaga eksekutif, legislatif, yudikatif, dan pers, seharusnya secara konsisten melaksanakan tugas dan fungsinya baik pada masa persiapan pemilihan umum (pre election) maupun pada masa setelah pemilihan umum (post election).

Pada masa sebelum pemilihan umum sampai dengan pelaksanaan pemilihan umum partai politik bertugas untuk memperoleh suara sebanyakbanyaknya untuk memperoleh jumlah kursi yang banyak di lembaga legislatif pada semua tingkatan, mulai dari DPR RI, DPRD Provinsi, dan DPRD Kabupaten/Kota. Sedangkan pada masa pasca pemilihan umum sampai dengan pelaksanaannya di periode selanjutnya, partai politik idealnya tetap harus melakukan kegiatan-kegiatan yang diarahkan pada tujuan organisasi dan mempersiapkan diri untuk menghadapi pemilihan umum di periode selanjutnya.

Hanya permasalahannya keberadaan partai politik sebagai pilar utama demokrasi, masih dililit persoalan klasik dan tak kunjung tuntas. Menurut Syamsuddin Haris persoalan klasik paratai politik adalah: (1) Partai politik dianggap masih memiliki problem ideologi, visi, dan haluan politik. Ideologi bukan hanya tidak jelas dan tidak dirumuskan secara spesifik, tetapi juga sekadar dokumen tertulis untuk memenuhi persyaratan undangundang; (2) Sebagian besar partai politik juga dinilai tidak memiliki basis sosial yang jelas dan spesifik; (3) Partai politik hanya bekerja menjelang pemilu dan "tidur panjang" di antara dua pemilu sehingga tidak terbangun format relasi yang melembaga dengan konstituen; (4) Partai politik belum berfungsi sebagai "jembatan" kepentingan rakyat dan pemerintah. Suara keras dan vokal partai politik juga belum tentu merupakan suara dan aspirasi rakyat; (5) Kepemimpinan personal lebih melembaga ketimbang kepemimpinan institusional. Sebagian besar partai politik tidak memiliki sistem kaderisasi yang jelas sehingga sumber rekrutmen politik cenderung bersifat oligarki; dan (6) Pada masa lalu partai politik merupakan wadah untuk mengabdi kepada bangsa, tetapi saat ini partai politik dipandang menjadi sarana untuk mengambil kepentingan tertentu. 
Simetris dengan Syamsuddin Haris, Wicipto Setiadi, menambahkan permasalahan partai politik, yaitu: (1) Pelembagaan partai politik, yakni partai politik belum melembaga sebagai organisasi modern, artinya proses pemantapan sikap dan perilaku partai politik belum terpola secara sistemik sehingga belum terbentuk budaya politik yang mendukung prinsip-prinsip dasar sistem demokrasi. Dalam konteks pembangunan politik, yang terpenting bukan jumlah partai politik yang ada, tetapi sejauh mana kekokohan dan adaptabilitas sistem kepartaian yang berlangsung. Sistem kepartaian yang kokoh sekurang-kurangnya memiliki dua kapasitas, yaitu: melancarkan partisipasi politik melalui jalur partai politik dan menyalurkan partisipasi sejumlah kelompok yang baru dimobilisasi; (2) Fungsi partai politikbelum berjalan secara maksimal baik fungsi partai politikterhadap negara, maupun fungsi partai politikterhadap rakyat. Fungsi partai politik terhadap negara adalah menciptakan pemerintahan yang efektif dan partisipasi politik terhadap pemerintahan yang berkuasa. Sedang fungsi partai politikterhadap rakyat adalah memperjuangkan kepentingan, aspirasi dan nilainilai pada masyarakat serta memberikan perlindungan dan rasa aman. Kebanyakan partai politik belum memberikan pendidikan politik dan melakukan pengkaderan serta rekrutmen politik yangefektif untuk menghasilkan kader-kader pemimpin yang memiliki kemampuan di bidang politik; dan (3) Kemandirian partai politik, yakni belum adanya kemandirian partai politik dalam pendanaan diluar iuran anggota dan subsidi negara. Iuran anggota pada sebagian besar partai politikrelatif tidak berjalan karena partai bersifat massa dan juga lemahnya mekanisme hadiah dan ganjaran dalam internal partai. Akibatnya partai politik senantiasa tergantung atau berharap pada sumbangan dari pemerintah dan pihak lain baik pribadi atau perusahaan. Hal ini mengakibatkan partai politiksibuk mencari tambahan dana partai, sedangkan pada saat yang sama partai politik harus memperjuangkan kepentingan rakyat.

Berdasarkan uraian diatas menarik untuk dilakukan sebuah kajian mengenaipermasalahan mendasar terhadap pengelolaan keuangan partai politik serta memberikan sebuah solusi terhadap permasalahan yang ada dengan membuat sebuah desain dalam pengelolaan keuangan partai politik yang berbasis demokrasi

\section{PERMASALAHAN PENGELOLAAN KEUANGAN PARTAI POLITIK}

Persoalan mendasar dalam pengeloaan keuangan partai politik (peserta pemilu dan non perserta pemilu) tidak adanya transparansi dan akuntabilitas dalam pengelolaan keuangan. Walaupun ada beberapa aturan dalam UU Partai Politik (UU UU No. 2 Tahun 2011 tentang Perubahan Atas UU No. 2 Tahun 2008 tentang Partai Politik) dan UU Pemilihan Umum (UU No. 15 Tahun 2011 tentang Penyelenggara Pemilihan Umum, UU No. 8 Tahun 2012 tentang Pemilihan Umum Anggota DPR, DPD dan DPRD, UU No. 42 Tahun 2008 tentang Pemilihan Umum Presiden dan Wakil Presiden, UU No. 8 Tahun 2015 tentang Perubahan Atas UU No. 1 Tahun 2015 tentang Penetapan Peraturan Pemerintah PenggantiI UU No. 1 Tahun 2014 tentang Pemilihan Gubernur, Bupati, dan Walikota MenjadiUU) yang memungkinkan publikasi laporan keuangan partai politik dan dana kampanye, aturan tersebut tidak dipergunakan secara luas dan tidak diimplementasikan dengan tegas.

Prinsip pengelolaan keuangan di dalam UU Partai politik dan UU Pemilu meliputi: sumber pendanaan; alokasi penggunaan keuangan; dan pelaporan penggunaan keuangan harus dikelola secara transparan, akuntabel dan auditebel. Selanjutnya permasalahan pengelolaan keuangan partai politikdapat diuraikan sebagai berikut:

\section{Sumber Pendanaan}

Pasal (34) UU Partai politik, menyebutkan bahwa setidaknya ada tiga sumber pendanaan partai politik, yaitu: iuran anggota, sumbangan yang sah menurut hukum, dan bantuan keuangan dari APBN/APBD. Permasalahan sumber pendanaan dari iuran anggota partai politik sangat sulit diharapkan dan boleh jadi hanya sebuah mimpi belaka. Hal ini disebabkan oleh beberapa hal, yaitu: (1) Tidak adanya kartu anggota; (2) Partai politik tidak memiliki peraturan operasional iuran anggota; (3) Partai politik tidak melaksanakan pungutan iuran anggota secara rutin; (4) Partai politik bersifat massa; dan (5) Lemahnya mekanisme hadiah dan ganjaran dalam internal partai. Intinya partai politik peserta pemilu di Indonesia tidak ada satupun partai politik membiayai kegiatannya berdasarkan iuran anggota.

Sumber dana utama untuk membiayai kegiatan partai adalah ketua umum dan kader 
partai yang duduk dalam lembaga legislatif dan eksekutif (elit internal partai); para pengusaha (yang mengharapkan kebijakan khusus seperti alokasi proyek, izin, dan jaminan keamanan dari kader partai yang memegang jabatan politik), individu, badan usaha swasta, organisasi dan kelompok (elit eksternal partai) baik yang diperoleh secara sah maupun secara tidak sah (private funding), dan uang negara (public funding) baik yang diperoleh secara sah maupun secara tidak sah.

Selanjutnya permasalahan terkait dengan sumbangan yang sah menurut hukum, yaitu: sumbangan perseorangan anggota partai politik yang pelaksanaannya diatur di dalam $\mathrm{AD} / \mathrm{ART}$ masing-masing partai politik dan sumbangan bukan anggota partai politik yang bersifat perseorangan dengan jumlah maksimum 1 miliar/tahun dan perusahaan maksimal 7 miliar/tahun, menurut Junaidi justru banyak memberi kelonggaran kepada partai politik dalam tata kerja keuangan organisasi. Maraknya wabah korupsi politik tidak lepas dari upaya partai untuk mencari sumbersumber pendanaan operasional partai. Aksi ini dilakukan melalui anggota-anggotanya yang duduk di berbagai posisi strategis di lembaga-lembaga negara maupun pemerintahan. Undang-undang melarang partai politik menerima dana dari APBN/ APBD ataupun BUMN/BUMD (bans against public funding), tetapi mengizinkan sumbangan dari kalangan swasta (private funding) namun keduanya dengan regulasi dan penegakan yang longgar. Partai politik melaksanakan tugas publik berdasarkan UUD 1945 dan UU tetapi pelaksanaan tugas publik tersebut dibiayai oleh unsur swasta. Sehingga yang terjadi kemudian tidak saja proses politik ditentukan oleh pemilik uang, tetapi juga partai politik yang memiliki kursi di DPR dan DPRD secara bersama-sama menggunakan kewenangan mengalokasikan anggaran untuk kepentingan partai dan pribadi (sistem kartel).

Menurut Michael Pinto-Duschinskyyang dikutip oleh situs Electoral Knowledge Network, mengatakan, bahwa korupsi dan penyalahgunaan kekuasaan yang berkaitan dengan pembiayaan partai politik dan kegiatan kampanye merupakan ancaman paling serius bagi demokrasi saat ini. Ancaman tersebut adalah: Pertama, adanya perlakuan istimewa bagi penyumbang besar dari kelompok kepentingan tertentu dan dapat melahirkan sejumlah pengaruh yang tidak proporsional. Meskipun tidak ada kepentingan tertulis dalam donasi besar, akan tetapi menerima sumbangan dalam jumlah besar dapat melahirkan persepsi adanya upaya membeli pengaruh maupun usaha mendapatkan perlakuan istimewa; Kedua, adanya anggapan bahwa pemilu pada dasarnya hanya dapat diikuti oleh kandidat atau individu yang kaya atau oleh mereka yang memiliki jaringan atau lingkaran pendukung kaya raya, sementara yang tidak memiliki cukup uang tidak akan dapat berkompetisi. Selain itu menurut Alfaqi yang dikutip dari jurnal ketahanan nasional mengatakan bahwa korupsi menyebabkan terganggunya pembangunan bangsa yang meliputi aspek ideologi, aspek politik, aspek ekonomi, aspek sosial budaya, aspek keamanan sehingga ketahanan wilayah tidak dapat terwujud dengan baik.

Subsidi negara yang diatur di dalam UU Partai politik dan Peraturan Pemerintah (PP) No. 83/2012 tentang Bantuan Keuangan kepada partai politik didasarkan pada jumlah perolehan suara dalam pemilu. Untuk menentukan nilai subsidi per suara, digunakan rumus jumlah subsidi APBN sebelumnya dibagi dengan jumlah suara partai politik yang mendapatkan kursi di DPR periode sebelumnya. Setelah nilai subsidi didapatkan, kemudian dikalikan dengan jumlah suara yang diperoleh pada pemilu terakhir. Sejak pemilu tahun 2009 sampai pemilu terakhir 2014 lalu, Mendagri menetapkan nilai subsidi per suara sebesar Rp 180. Permasalahannya besaran bantuan negara kepada partai politik sesungguhnya bernilai kecil dibandingkan waktu-waktu sebelumnya. Ketika subsidi negara masih diatur PP No. 51Tahun 2001 Tentang Bantuan Keuangan Kepada Partai Politik, nilai subsidi untuk satu suara ditetapkan Rp 1.000. PP 29/2005 nilai subsidi ditetapkan sebesar Rp 21 juta untuk satu kursi di DPR, bukan per suara. Selanjutnya PP No. 5/2009 dan PP 83/2012 Tentang Perubahan Atas Peraturan Pemerintah Nomor 5 Tahun 2009 Tentang Bantuan Keuangan Kepada Partai Politik, justru menjadi lebih rumit dibandingkan dengan PP sebelumya.

\section{Alokasi Penggunaan Anggaran}

Permasalahan terkait dengan alokasi penggunaan anggaran oleh partai politik, di dalam UU Partai politik dan UU Pemilu tidak diatur atau dirinci sumber pendanaan partai politikdan belanja partai politik. UU hanya menyebutkanbantuan atau subsidi negara kepada partai politikyang diprioritaskan untuk kegiatan pendidikan politik 
(sedikitnya $60 \%$ sebagaimana yang diatur kemudian oleh PP). Selebihnya penggunaan subsidi dan keuangan partai politik secara umum tidak disebutkan dan diatur lebih lanjut oleh UU. Hal yang sama juga tidak adanya batasan biaya kampanye, tetapi yang diatur hanya besaran sumbangan.

Terbatasnya pengaturan belanja partai politik mengindikasikan, bahwa UU Partai Politik hendak membebaskan partai politik dalam belanja dan berbanding lurus dengan pendapatan dari sumbangan perseorangan anggota yang juga tidak dibatasi. UU Partai politik membiarkan partai politik dikuasai seorang atau sekelompok orang anggota. Implikasi atas sedikitnya pengaturan belanja dan tiadanya pembatasan terhadap belanja partai politik, secara administrasi keuangan akan menyulitkan penyusunan laporan keuangan partai politik. Sedang secara organisasi membiarkan partai politik tidak bertanggungjawab atas belanjanya. Partai politik bisa saja terus mengatakan pihaknya membutuhkan dana besar untuk menggerakkan organisasi tanpa mengetahui sampai di mana batas belanjanya. Akibatnya demi mendapatkan dana yang tidak terbatas tersebut, partai politik membuka diri untuk mendapatkan sumbangan sebanyak-banyaknya.

Pola pengeluaran partai politik terkonsentrasi pada dua kegiatan. Pertama, persiapan dan penyelenggaraan pertemuan partai lima tahunan (Kongres, Musyawarah Nasional atau Muktamar) untuk memilih ketua umum dan pengurus baru lainnya dan perumusan program partai dan pertemuan tahunan untuk menyusun rencana pelaksanaan program partai. Kedua, kegiatan pencalonan dan kampanye pemilihan umum anggota DPR, DPRD Provinsi dan DPRD Kabupaten/Kota, dan Pemilu Presiden dan Wakil Presiden. Sebagian besar pengeluaran partai politik dialokasikan untuk membiayai kedua kegiatan ini, oleh karenanya banyak pendapat yang menyatakan mengapa partai politik di Indonesia dilukiskan sebagai lebih berorientasi pada mencari dan mempertahankan kekuasaan baik dalam partai maupun dalam pemerintahan (power seeking) daripada berorientasi pada perumusan pola dan arah kebijakan publik dalam berbagai isu publik (policy seeking).

Pengeluaran lain yang kurang tepat dari partai politik adalah untuk membiayai kegiatan administrasi partai dan perkantoran (seperti sewa kantor, alat kelengkapan kantor, rekening listrik dan air, gaji pegawai, konsumsi rapat, dan transportasi). Beberapa partai politik melakukan kaderisasi anggota tetapi tidak berjenjang dan sistematik. Sebagian partai melakukan kegiatan ulang tahun partai dengan gerak jalan sehat, kunjungan ke panti asuhan, dan kegiatan sunatan. Sejumlah partai mengontrak lembaga survey untuk mengetahui elektibilitas partai ataupun ketua umum.

\section{Pertanggungjawaban Keuangan}

Permasalahan utama terhadap pertanggungjawaban keuanganpartai politik adalah tidak adanya laporan pertanggungjawaban penerimaan dan penggunaan keuangan partai politik. Kondisi tersebut jelas tidak baik bagi kehidupan partai politik sendiri maupun demokrasi secara luas. Padahal prinsip akuntabilitas dan transparansi sudah diadopsi oleh UU Partai politik dalam mengatur penggunaan dan pelaporan keuangan partai politik. Transparansi dan akuntabilitas yang sudah tertuang dalam UU, tetapi hanya dianggap sebagai pemanis semata karena nyaris tidak berjalan sama sekali.

Laporan pertanggungajawaban keuangan partai politik mulai dari rekening kas umum partai politik, daftar penyumbang, laporan realisasi anggaran, neraca, kas atas pemasukan dan pengeluaran keuangan partai politik memang sudah diatur dalam UU Partai politik, tetapi belum atau tidak bisa membuat partai politik bersikap transparan, akuntabel dan bertanggungjawab. Hanya penggunaan keuangan yang bersumber dari subsidi negara atau APBN saja yang diatur lebih baik oleh UU. Dana subsidi negara setiap tahun diaudit oleh Badan Pemeriksa Keuangan (BPK), sebelum disampaikan kepada pemerintah. Publik bisa mengetahui audit atas penggunaan bantuan APBN oleh partai politik melalui laporan hasil pemeriksaan BPK.

Permasalahan selanjutnya adalah ketidaktegasan pemerintah dalam memberi sanksi, membuat partai politik tetap lalai dalam memberikan laporan pertanggungjawaban keuangan partai politik atas subsidi negara. Ketika laporan pertanggungjawaban keuangan dari subsidi negara saja tidak sesuai dengan ketentuan peraturan yang ada, maka bisa dipastikan bagaimana bentuk pertanggungjawaban keuangan partai politik atas sumber pendanaan yang tidak berasal dari negara.

Selanjutnya UU Partai politik secara tegas meminta akuntabilitas dan tanggung jawab partai 
politik atas penggunaan keuangan non-subsidi negara, tetapi UU ini mengabaikan prinsip transparansi itu sendiri. Pengabaian prinsip transparansi ditunjukkan dengan ketiadaan aturan bagi partai politik untuk menyampaikan hasil audit akuntan publik.

Hal yang sama juga tidak diterapkannya prinsip kesetaraan antar partai politik peserta pemilu. Setidak-tidaknya terdapat 4 (empat) prinsip kesetaraan yang harus diterapkan, yaitu: Pertama, setiap partai politik peserta pemilu menerima dana dari negara. Misalnya 30\% dari pengeluaran partai untuk pelaksanaan fungsi partai; Kedua, besarnya sumbangan yang dapat diterima dari individu, kelompok ataupun badan usaha nonpemerintah tidak boleh melewati jumlah tertentu; Ketiga, larangan beserta sanksinya terhadap praktek jualbeli suara sehingga setiap peserta pemilu bersaing menggunakan cara-cara yang dibenarkan oleh undang-undang; danKeempat, pemasangan/ penyiaran iklan kampanye pemilu setiap peserta pemilu dengan durasi dan frekuensi yang sama melalui media massa yang dibiayai oleh negara. Dengan demikian jika prinsip kesetaraan diterapkan, maka partai politikpeserta pemilu yang memiliki program yang baik dan calon yang berkualitas tetapi tidak memiliki dana yang memadai, partai politik tetap dapat bersaing mendapatkan simpati dari para pemilih.

Permasalahan lain adalah tidak adanya institusi yang ditunjuk UU untuk menerima laporan audit akuntan publik, sebagaimana pemerintah menerima laporan audit BPK atas penggunaan subisidi negara.

\section{DESAIN PENGELOLAAN KEUANGAN PARTAI POLITIK BERBASIS DEMO- KRASI}

Dalam kerangka mewujudkan pengelolaan keuangan partai politik berbasis demokrasi, desain pengelolaan keuangan partai politik harus dikembangkan dari prinsip-prinsip demokrasi itu sendiri, yaitu: transparansi, akuntabilitas,dan kesetaraan.

Tranparansi dalam United Nations Development Programme (UNDP) adalah: tersedianya informasi secara bebas dan dapat diakses secara langsung (directly accessible) kepada pihak-pihak yang terkena dampak oleh suatu pelaksanaan keputusan; informasi disediakan dengan isi yang mudah untuk dipahami; sistem yang transparan memiliki yang jelas dalam pengambilan keputusan publik; adanya saluran komunikasi informasi antara stakeholder dan birokrat.

Akuntabilitas dalam The oxford advance learner's "Dictionary, berarti dapat dipertanggungjawabkan, dapat ditelusuri, dapat dijelaskan, dapat menjawab pertanyaan yangdijukan mengenai account atau deskripsi/ penjelasan dari sesuatu yang telah terjadi. Sedang dalam UU No. 28 Tahun 1999 tentang Penyelenggara negara Yang Bersih dan Bebas dari Korupsi, Kolusi dan Nepotisme, asas akuntabilitas adalah asas yang menentukan bahwa setiap kegiatan dan hasil akhir dari kegiatan penyelenggaraan negara harus dapat dipertanggungjawabkan kepada masyarakat atau rakyat sebagai pemegang kedaulatan tertinggi negara yang sesuai dengan ketentuan peraturan perundang undangan yang berlaku.

Sedang kesetaraan Rothbardian dari artikel J.B. Wolftein mengelompokan 3(tiga) macam kesetaraan, yaitu: 1) Kesetaraan secara politik, artinya hak terhadap kehidupan, kebebasan dan kepemilikan, tanpa gangguan dari pihak eksternal terhadap hal-hal tersebut; 2) Kesetaraan secara ekonomi, yang esensinya adalah kesamaan pendapatan atau kekayaan; 3) Kesetaraan secara sosial, yang dapat berupa: (a) kesamaan status sosial, (b) kesetaraan dalam kesempatan, atau (c) kesamaan perlakuan, atau (d) kesamaan pencapaian.

Menurut Breth dan Quibell sebagaimana dikutip Djayadi Hanan, pengelolaan keuangan yang transparan, akuntabel dan kesetaraan akan membawa berpengaruh atas persepsi positif atau negatif terhadap suatu partai politik sekaligus sinergitas dalam pemerintahan. Transparansi dan akuntabel merupakan satu dari tiga praktek terbaik yang harus dijalankan oleh partai politik dalam sistem demokrasi. Dua praktek lainnya yaitu demokrasi internal dan penjangkauan masyarakat. Partai politik yang menjalankan praktek transparansi selalu memberikan laporan keuangan, sumber-sumber bantuan, biaya yang dikeluarkan dan asset partai politik kepada anggota internal partai sendiri dan kepada masyarakat sekalipun itu tidak diminta.

Proses mewujudkan keterbukaan pengelolaan keuangan partai politik berbasis demokrasi internal partai politik adalah dengan melakukan "pelembagaan" partai politik. Sistem kepartaian yang kuat akan menyediakan organisasi 
partai politik yang mengakar dan prosedur yang melembaga guna mengasimilasikan kelompok baru ke dalam sistem politik. Adapun mekanisme penguatan pelembagaan partai politik dapat dilakukan melalui: (1) Pengakaran partai (party rooting), yaitu pada level akar rumput, level pusat dan level pemerintahan; (2) Legitimasi partai (party legitimacy), yaitu partai politik secara kontinyu menjalankan fungsi-fungsinya yang terhubung langsung dengan masyarakat, seperti: pendidikan politik, sosialisasi dan komunikasi politik dan agregasi kepentingan yang lebih luas; (3) Aturan dan regulasi (rule and regulation), yaitu penguatan partai politik dengan menciptakan kejelasan struktur dan aturan kelembagaan dalam berbagai aktivitas partai baik di pemerintahan, internal organisasi maupun di akar rumput; dan (4) Daya saing partai (party competitiveness), yaitu kapasitas atau tingkat kompetensi partai untuk berkompetisi dengan partai lain dalam arena pemilu dan kebijakan publik.

Selanjutnya untuk mendorong kemandirian keuangan partai politik, Veri Junaidi menawarkan solusi sebagai berikut: (1) Pendanaan publik diharapkan mampu memecah konsentrasi pendanaan pemodal yang bisa menjauhkan partai dari kepentingan publik/rakyat; (2) Optimalisasi iuran anggota partai politik. Optimalisasi iuran anggota tidak hanya semata-mata untuk menguatkan keuangan partai, tetapi untuk mendekatkan diri dengan anggota/konstituen/ pemilih melalui kebijakan-kebijakan yang pro terhadap rakyat; (3) Menaikkan subsidi negara melalui kebijakan yang menjadi pemantik untuk menghidupkan iuran anggota. Kebijakan seperti pemberian insentif bagi partai politik yang mampu menggalang iuran anggota/pemilih; dan (4) Penguatan implementasi prinsip transparansi dan akuntabilitas pengelolaan dan penggunaan keuangan partai menjadi prasarat yang harus dipenuhi oleh partai politik.

Sementara itu, Wicipto Setiadi menawarkan sebagai berikut: (1) Adanya laporan pertanggungjawaban keuangan partai yang transparan, akuntabel dan auditable sehingga mendorong tingginya tingkat kepercayaan anggota dan masyarakat terhadap partai politik dalam mengelola keuangan dan kekayaannya; (2) Pemerintah harus mendorong partai politik untuk mandiri dengan cara menguatkan manajemen, menyederhanakan jumlah partai politik, dan menegakkan hukum politik; dan (3) Perlu pengaturan pembatasan besaran biaya kampanye. UU No. 2 Tahun 2011 hanya mengatur besaran jumlah subsidi negara dan sumbangan pihak ketiga.Beberapa alasan mengapa partai politik harus mandiri adalah: (1) Menjaga independensi sebagai pengawas jalannya pemerintahan;(2) Mencegah kekacauan peran dan kewenangan; dan (3) Mencegah praktik KKN.

Konkritnya upaya mewujudkan pengelolaan keuangan partai politik berbasiskan demokrasi menuju kemandirian partai politikdapat dirumuskan sebagai berikut:

\section{Sumber pendanaan}

Perlunya pengaturan secara komperhensif dalam UU tersendiri atau dalam UU Partai politik dan UU Pemilu tentang sumber penerimaan, jenis pengeluaran, pengelolaan, pertanggungjawaban, larangan, prosedur penegakan ketentuan, berbagai jenis sanksi dan beserta institusi penegakan ketentuan keuangan partai politik.

Untuk menjamin transparansi penerimaan dan pengeluaran partai politik, maka dalam penerimaan sumber dana harus jelas disebutkan hal-hal berikut: (1) Identitas lengkap setiap sumber penerimaan: nama, tempat dan tanggal lahir, alamat tempat tinggal, nomor telepon rumah/seluler, pekerjaan, kedudukan dalam pekerjaan, alamat tempat pekerjaan, dan nomor telepon kantor, apabila badan usaha yang telah go public yang menjadi penyumbang, maka harus pula disebutkan nama pemilik saham dan komposisi pemilihan saham; dan (2) Jumlah dari setiap jenis dan bentuk sumbangan (uang, barang, jasa; potongan harga, pinjaman, hadiah).

Untuk meningkatkan penghasilan partai yang didapatkan secara legal,adalah dengan menaikkan sumbangan dari masyarakat dan mengoptimalkan iuran anggota partai politik.Di banyak Negara, sumbangan didorong melalui sistem pengurangan pajak terhadap para penyumbang. Tentunya pengurangan pajak ini hanya diberikan kepada penyumbang yang menyerahkan sumbangannya langsung ke kas partai dan dicatat secara resmi. Sedang upaya optimalisasi iuran anggota partai politik dapat dilakukan sebagai berikut: (1) Mengubah tipe partai kharismatik dan klientelistik menuju tipe partai programatik; (2) Penyederhanaan sistem kepartaian dalam pemilu; (3) Mengembalikan sifat partai politik dari partai massa ke partai kader; (4) Menertibkan kembali kartu anggota partai politik; dan (5) Pengaturan 
partai politik peserta pemilu dengan parameter kelayakan admiistratif dan legitimasi partai politik, yaitu partai politik yang sudah menjalankan fungsifungsinya (pendidikan politik, sosialisasi dan komunikasi politik dan agregasi kepentingan) di masyarakat.

Perlunya mempertimbangkan kembali untuk menaikkan jumlah bantuan APBN dan APBD kepada partai politik. Pada tahun 2001, jumlah tersebut pernah mencapai Rp. 1.000 per suara, namun kemudian terjadi penurunan yang sangat drastis pada tahun 2005, sebesar 90 persen. Saat ini partai politik hanya menerima Rp. 108 per suara. Penurunan ini telah memperburuk situasi keuangan partai-partai dan meningkatkan ketergantungan mereka pada kepentingan oligarkis.

Perlu adanya satu lembaga yang mengawasi pelaporan dan penggunaan dana politik. Saat ini KPU mengawasi dana kampanye, Polisi bertanggungjawab terhadap pelanggaran yang bersifat pidana, dan BPK memeriksa penggunaan uang partai politik dari APBN dan APBD. Bawaslu dapat mengambil alih peran KPU dalam pengawasan dana kampanye. Di banyak negara demokrasi semua tugas pengawasan dana kampanye dijalankan oleh satu lembaga dan dibantu oleh kantor akuntan publik yang ditunjuk.

\section{Alokasi Penggunaan Anggaran}

Permasalahan utama penggunaan anggaran adalah penggunaan anggaran yang tidak mencerminkan fungsi partai politik. Pengeluaran terbesar digunakan untuk membiayai Kongres/ Munas/ Muktamar dan proses pencalonan dan kampanye pemilu dan untuk kegiatan operasional sekretariat dan kegiatan pendidikan politik. Seharusnya kegiatan yang mencerminkan fungsi partai politik mencakup rekrutmen, kaderisasi, dan representasi politik.

Konkritnya dana partai politik seharusnya digunakan untuk membiayai kegiatan yang menyangkut fungsi partai politik dalam sistem politik demokrasi, yaitu: Pertama, rekrutmen warga negara menjadi anggota partai politik dalam hal ini menurut Ruslan dan Abdar rekrutmen yang dimaksud adalah menggunakan sistem terbuka yang mencerminkan sikap demokratis dalam menentukan syarat dan proses yang ditempuhdalam menjaring calon elit politik, dan orientasi politik (pengenalan partai) bagi anggota baru; Kedua, kaderisasi secara berjenjang (mulai dari tingkat kabupaten, provinsi sampai tingkat nasional) bagi anggota partai baik mengenai ideologi partai maupun mengenai kompetensi yang diperlukan untuk menjadi kader partai, menjadi anggota badan perwakilan rakyat ataupun peran politik lainnya dalam pemerintahan; Ketiga, berdialog mendengarkan masukan ataupun aspirasi konstituen pada akar rumput (kegiatan representasi politik) untuk kemudian merumuskannya berdasarkan ideologi partai politik menjadi rencana pola dan arah kebijakan publik dalam berbagai isu pemerintahan; Keempat, mengontrak konsultan politik untuk memberikan masukan kepada pengurus partai sebelum membuat keputusan partai mengenai calon kepala pemerintahan dan mengenai visi, misi dan program pembangunan nasional; dan Kelima, persiapan dan pelaksanaan pemilihan pendahuluan oleh anggota partai untuk membahas dan memilih calon anggota DPR/DPRD ataupun kepala pemerintahan dan/atau membahas rencana pola dan arah kebijakan publik dari partai.

\section{Pertanggungjawaban keuangan}

Beberapa usulan terkait dengan pertanggungjawaban keuangan partai politik, Ramlan Surbaktimengusulkan sebagai berikut:

a. Setiap pengurus partai politik tingkat nasional dan pengurus partai politik provinsi dan tingkat kabupaten/kota), wajib menyerahkan laporan penerimaan dan pengeluaran partai kepada kantor akuntan publik yang ditetapkan sesuai dengan format yang ditentukan. Lembaga yang berwenang menindaklanjuti hasil audit terhadap laporan penerimaan dan pengeluaran Partai diumumkan kepada publik melalui Website dan media massa maupun dengan melakukan penyelidikan lebih lanjut bila ditemukan bukti awal penyimpangan dalam Hasil Audit tersebut.

b. Partai politik peserta pemilu wajib melakukan: (1) Secara periodik melaporkan kepada publik melalui KPU setiap sumbangan yang di terima untuk kegiatan kampanye pemilu; (2) Melaporkan penerimaan dari pihak yang dilarang oleh undang-undang kepada lembaga yang berwenang dan menyetorkan dana tersebut kepada Kas Negara; dan (3) Menyampaikan laporan penerimaan dan pengeluaran dana kampanye pemilu menurut jadwal dan format yang ditetapkan.

c. Setiap partai peserta pemilu untuk setiap tingkatan wajib: (1) Membuka rekening khusus dana kampanye di Bank yang sama; (2) Seluruh uang masuk dan keluar dari partai 
politik harus tergambar pada rekening khusus dana kampanye pemilu; dan (3) Memberikan izin bagi kantor akuntan publik membuka rekening khusus dana kampanye.

d. Setiap laporan yang disampaikan kepada publik harus dalam format yang mudah diakses (easily accessible format) dan dalam bentuk yang mudah dibaca dan dipahami oleh publik (in user-friendly).

e. Pengurus partai politik wajib menjawab pertanyaan, permintaan klarifikasi atau permintaan informasi/data/dokumen dari petugas lembaga yang berwenang menegakkan ketentuan keuangan partai politik perihal dugaan kemungkinan adanya penyimpangan dalam keuangan partai politik.

f. Perlunya dibentuk institusi yang diberi kewenangan menegakkan ketentuan tentang keuangan partai politik seperti yang diberlakukan di berbagai negara.

\section{SIMPULAN}

1. Persoalan mendasar dalam pengeloaan keuangan partai politik (peserta pemilu dan non perserta pemilu), mulai dari sumber pendanaan, alokasi penggunaan anggaran dan pelaporan pertanggungjawaban adalah tidak adanya transparansi dan akuntabilitas dalam pengelolaan keuangan partai politik.

2. Terdapat 5 (lima) permasalahan utama mengenai pengelolaan keuangan partai politik di Indonesia, yaitu: (1) UU Partai politik dan UU Pemilu tidak mengatur secara rinci sumber pendanaan partai politik dan belanja partai politik. UU hanya menyebutkan bantuan atau subsidi negara kepada partai politik, tetapi tidak member batasan besaran dana kampanye; (2) Jumlah penerimaan resmi yang sangat kecil dan tidak mencukupi seluruh pengeluaran partai politik; (3) Pola pengeluaran lebih didominasi untuk pembiayaan politik (seperti kegiatan munas/kongres dan proses Pemilu) ketimbang melakukan pendidikan politik sebagai salah satu fungsi utama partai politik; (4) Pembukuan

\section{DAFTAR RUJUKAN}

Adnan Topan Husodo, 2012, Pengaturan Dana Kampanye dan Implikasinya Terhadap Praktek Korupsi Pemilu, Jurnal Pemilu dan Demokrasi, Yayasan Perludem Jakarta. yang tidak dilakukan dengan tertib administrasi; dan (5) Tidak adanya institusi yang memfokuskan diri pada penanganan permasalahan pengelolaan keuangan partai politik.

3. Desain pengelolaan keuangan partai politik yang berbasis demokrasi mulai dari sumber pendanaan, alokasi penggunaan anggaran dan pelaporan pertanggungjawaban, harus dekelola dengan prinsip-prinsip demokrasi itu sendiri, yaitu: transparansi, akuntabilitas, dan kesetaraan. Tidak ada demokrasi tanpa partai politik. Partai politik adalah produk dari kebebasan berfikir, berpendapat, berserikat dan berkumpul. Partai politik merupakan alat bagi rakyat dalam menjalankan kedaulatan rakyat dan pemilihan umum merupakan mekanisme untuk menentukan pilihan rakyat terhadap partai politik. Upaya mewujudkan demokrasi sejati, sebaiknya partai politik mampu memperkuat jajaran pimpinan dan kepengurusan, mandiri dalam masalah keuangan sehingga tidak tergantung pada pemerintah, mampu menyelesaikan konflik internal secara damai dan mampu melaksanakan kegiatan-kegiatan partai sebagai sarana untuk pemberdayaan rakyat. Adapun prosesnya melaui "pelembagaan" partai politik dengan cara pengakaran partai (party rooting), legitimasi partai (party legitimacy), aturan dan regulasi (rule and regulation), dan mengembangkan daya saing partai (party competitiveness).

4. Upaya mewujudkan kemandirian keuangan partai politik dapat dilakukan dengan cara: (1) Pendanaan publik; (2) Optimalisasi iuran anggota partai politik; (3) Menaikkan subsidi negara; (4) Penguatan implementasi prinsip transparansi dan akuntabilitas pengelolaan dan penggunaan keuangan partai; (5) Pemerintah harus mendorong partai politik untuk mandiri dengan cara menguatkan manajemen, menyederhanakan jumlah partai politik, dan menegakkan hukum politik; dan (6) Perlu pengaturan pembatasan besaran biaya kampanye.
Alfaqi, M., Habibi, M., \& Rapita, D. (2017). Peran Pemuda dalam Upaya Pencegahan Korupsi dan Implikasinya Terhadap Ketahanan Wilayah.Jurnal Ketahanan Nasional, 
23(3), 320-337. /*doi:http://dx.doi.org/ 10.22146/jkn.27695*/ doi:https://doi.org/ $10.22146 / \mathrm{jkn} .27695$

Didik Supriyanto, 2012, Kebijakan Bantuan Keuangan Partai Politik: Review terhadap PP No. 5/2009 Dalam Rangka Penyusunan Peraturan Pemerintah Baru Berdasar UU No. 2/2011, Dalam Jurnal Pemilu dan Demokrasi Perludem, Kemitraan Bagi Pembaharuan Tata Pemerintahan, Jakarta.

Djayadi Hanan, 2015, Partai politik dan Persepsi Publik, Opini, Kompas, 11 April 2015.

Ekamara Ananami Putra, 2015, Reformasi Keuangan Partai Politik: Peluang Mencegah Korupsi Politik Di Era Revolusi Mental,http://www.academia.edu /12436200/Reformasi _Keuangan_Partai politik.

J.B. Wollstein, The Idea of Equality, yang diterbitkan oleh The Freeman: Ideas on Liberty-April 1980; Vol. 30 No. 4. Versi online artikel ini dapat diunduh dari http:// akaldankehendak.com.)

Komite Pemantau Legislatif (KOPEL) dan Kemitraan, Pembiayaan Partai Politik Sulawesi Selatan, 2013, Makassar: KOPEL dan Kemitraan.

Michael-Pinto Duschinsky, 2011, Ilmuwan Politik yang Menekuni Bidang Pendanaan Politik, Kampanye dan Korupsi Politik. Buku terbaruya "Bringing Rights Back Home" yang diterbitkan Policy Exchange.

Ramlan Surbakti, 2015, Peta Permasalahan Dalam Keuangan Politik Indonesia, Kemitraan Bagi Pembaharuan Tata Pemerintahan, Jakarta.

Syamsuddin Haris, 2014, Sarasehan Komisi Pemilihan Umum (KPU) dengan Media Massa, LSM, dan Ormas bertajuk " $K P U$ Menyongsong Pemilu 2014" di Jakarta.

Veri Junaidi, Dkk. 2012, Anomali Keuangan Partai Politik: Pengatuan dan Praktek, Dalam Jurnal Pemilu dan Demokrasi Perludem, Kemitraan Bagi Pembaharuan Tata Pemerintahan, Jakarta.

Wicipto Setiadi, 2008, Peran Partai Politik dalam Penyelenggaraan Pemilu yang
Aspiratif dan Demokratis, Jurnal Legislasi Indonesia, Sistem Multipartai Di Indonesia, Vol. 5 No.1.

Republik Indonesia, Undang Undang Dasar Negara Republik Indonesia Tahun 1945.

Republik Indonesia, Undang Undang Nomor 28 Tahun 1999 Tentang Penyelenggara Negara Yang Bebas Dari Korupsi, Kolusi Dan Nepotisme.

Republik Indonesia. 2008. Undang Undang Republik Indonesia Nomor 42 Tahun 2008 tentang Pemilihan Umum Presiden dan Wakil Presiden.

Republik Indonesia, Undang Undang Republik Indonesia Nomor 2 Tahun 2011 Tentang Perubahan Atas Undang Undang Nomor 2 Tahun 2008 Tentang Partai Politik.

Republik Indonesia, Undang Undang Nomor 15 Tahun 2011 tentang Penyelenggara Pemilihan Umum.

Republik Indonesia, Undang Undang Republik Indonesia Nomor 8 Tahun 2012 Tentang Pemilihan Umum Anggota DPR, DPD dan DPRD

Republik Indonesia, Undang Undang Republik Indonesia Nomor 8 Tahun 2015 tentang Perubahan Atas Undang Undang Nomor 1 Tahun 2015 Tentang Penetapan Peraturan Pemerintah PenggantiI Undang Undang Nomor 1 Tahun 2014 tentang Pemilihan Gubernur, Bupati, dan Walikota Menjadi UU.

Republik Indonesia, Peraturan Pemerintah Nomor 51 Tahun 2001 Tentang Bantuan Keuangan Kepada Partai Politik.

Republik Indonesia, Peraturan Pemerintah Nomor 83 Tahun 2012 Tentang Perubahan Atas Peraturan Pemerintah Nomor 5 Tahun 2009 Tentang Bantuan Keuangan Kepada Partai Politik.

Ruslan, R., \& Abdar, Y. (2016). Pola Rekrutmen Calonlegislatif Dapil 1 Provinsi Aceh yang Dilakukan oleh Partai Keadilan Sejahtera (PKS) Dan Partai Nasional Demokrat (Nasdem). Jurnal Ilmiah Pendidikan Pancasila dan Kewarganegaraan, 1(2), 111-114. doi: http://dx.doi.org/10.17977/ jippk.v1i2.827 